Trinity College

Trinity College Digital Repository

Faculty Scholarship

Winter 2003

Powerlessness Grows out of the Barrel of a Gun

Vijay Prashad

Trinity College, Vijay.Prashad@trincoll.edu

Follow this and additional works at: https://digitalrepository.trincoll.edu/facpub

Part of the Peace and Conflict Studies Commons 


\title{
Powerlessness Grows Out of the Barrel of a Gun
}

\author{
Vijay Prashad
}

I heard about 9/11 from my sister-in-law, who called and said that something terrible had just happened. Without cable television and with only intermittent Web gazing during the morning, I may have spent the day in beautiful Northampton, Massachusetts, oblivious to the clash of fundamentalisms, to another episode of Mcjihad. ${ }^{1}$ But the contradictions intervened, and I sat down and wrote a brief piece called "Nothing Good Comes from Terror."

The short note, which went out on the Internet from ZNET that evening, ended with the following words:

The attacks must be condemned without reservation. But we must be certain to recognize that these are probably the work of frustrated and alienated human beings hemmed in by forces that are anonymous and that could only be embodied by these structures. The people who work in them became the "collateral damage" that we hear so much about when our cruise missiles strike the Third World. Those who died are martyrs of this government's insane policies, as well as martyrs of the insanity of neoliberal globalization.

Even as I typed those words, I was thinking of one of my favorite figures from our past, the great Bhagat Singh. ${ }^{2}$ Born in 1907 to a prosperous family in Lyallpur, western Punjab, Bhagat Singh was swept up in the anticolonial fervor of his days. Inspired by his freedom fighter uncle, Sardar Ajit Singh, Bhagat Singh joined his fellow students as they threw their bodies on the line to force British imperialism to

Radical History Review

Issue 85 (winter 2003): 124-32

Copyright 2003 by MARHO: The Radical Historians' Organization, Inc. 
flee the subcontinent. When Punjabi revolutionary peasants formed the Ghadar Party in San Francisco in 1913, they sent a message across the subcontinental diaspora that the masses of Indians were ready to be organized for militant action. The voluble Congress Party (formed in 1885) had not done its duty, and it was in the diaspora - in the United States with the Ghadarites and in South Africa with the miners and cane workers mobilized alongside M. K. Gandhi-that the fiery spirit of mass organization of Indians took hold. The Ghadarites and Gandhi imported this spirit back into the subcontinent and seized the patriotic energy of people like Bhagat Singh.

In September 1928, Bhagat Singh, only twenty-one and already a veteran militant, became the secretary of the Hindustan Socialist Republican Association (HSRA) whose goal was nothing less than the creation of a socialist republic of India. The next month, the liberal wing of British imperialism sent the Simon Commission to condescendingly ascertain the views of the people, so the HSRA decided to boycott it, but also to protest its presence. At a major demonstration joined by patriotic forces of all kinds in Lahore, Punjab, on October 30, 1928, the imperialist police smashed the protesters and killed the Lion of Punjab, Lala Lajpat Rai, who had just returned to India from his sojourn in New York City. Vengeance for this murder came when Bhagat Singh and his group assassinated an important police official, John Poyantz Saunders, in late 1928. Then, the next year, as the British government tried to curtail civil liberties and workers' rights through legislative action, the HSRA decided to conduct a terrorist act on the legislature. On April 8, as the president of the legislature announced that the bills against civil action had been passed, Bhagat Singh and Batukeshwar Dutt threw one bomb each and countless leaflets into the well of the chamber; loud noises, they wrote in a leaflet, are needed to make the deaf hear their cries. The police arrested Bhagat Singh, sentenced him to die, and finally executed him on March 23, 1931.

A young man born in the midst of desperate oppression, turned, like many in his generation, to an impatient strategy to resolve the nation's problems. In December 1928, Bhagat Singh met the veteran Ghadar Party member and later communist leader Sohan Singh Josh. Josh worried that Bhagat Singh's group would go the way of many small bands of militant young people, men and women alike, who tried to take on the British Empire with their homemade weaponry and their blind faith in a Sorelian kind of violence. In 1902, Bengali revolutionaries formed the Anushilan Samiti; by 1907, the Marathis moved to terrorism through the Abhinava Bharat group; and in the next year, radicals in Tuticorin, Tamil Nadu, conducted acts of terror against symbols of British rule. The HSRA in Punjab brought this spirit of terror to bear in the province from where the British continued to recruit their global imperialist army, and to draw immense amounts of grain from the productive soil and the toil of the peasantry. The historical record contains powerful symbols from this period, such as the last words of the executed Kartar Singh Sarabha (who 
organized a mutiny among the Punjabi troops in 1915): "If I had to live more lives than one, I would sacrifice each of them for my country's sake." Or else those of Abdullah (a rebel soldier who refused to betray his non-Muslim comrades in 1915), "It is with these men alone that the gates of heaven shall open to me."3 The bands of terror provoked the British to offer a fierce response, now justified by the acts of violence conducted by the young patriots. In March 1915, the Defense of India Act enabled the British to arrest hundreds of militants, hold them without habeas corpus, and execute the most dangerous to the empire. Such laws and ordinances litter the history of India from that day until the departure of the British, and onward.

If the Congress Party remained an elitist force because it did not go among the masses until Gandhi returned to India in 1915, the terrorists suffered from the same problem: they claimed to speak for a people whom they did not seek to organize. Josh pointed this out to Bhagat Singh, who replied that "we entirely agree with the programme and activities of your party, but there are times when the blow to the enemy has to be immediately counteracted by armed actions to inspire confidence among the masses." 4 Josh had an easy rejoinder, a long 1924 article published by the Communist Party of India (CPI) from its exiled offices in Central Asia. Keep in mind that Gandhi, then already on the front page of the Indian movement, did not have a lock on nonviolence, for although he fashioned it into a unique and important theory of political work, the idea of nonviolent action has a long tradition on the left (strikes, marches, civil disobedience, etc.):

No less futile is sporadic terrorism carried on by secret societies. Those who resort to the futility of this extremism possess an equally wrong conception of revolution. Violence is not a personal essential attribute of revolution. Under the present state of society, political and social revolutions can hardly be expected to be bloodless and nonviolent, but everything bloody and violent is not revolutionary. A particular social system or political institution can never be overthrown by assassinating individuals upholding them. It is no more possible to win national independence by killing a number of officials than by a series of reform acts passed by the British parliament. One method is as impotent as the other, because none of them strikes at the root of the evil. Both are political blunders. ${ }^{5}$

The refusal of random violence marked the communist movement, even as the police and propaganda forces pronounced otherwise. In Capital, Marx wrote, "Force is the midwife of every old society pregnant with a new one. It is itself an economic power." Where the social relations of capital had attained maturity, however, "the dull compulsion of economic relations completes the subjection of the laborer to the capitalist. Direct force, outside economic conditions, is of course still used, but only exceptionally."6 
The history of the subjugation of the oil lands is, certainly, a history of violence and suffering, of enforced poverty and illiteracy — especially in that condition called the tolerance of Arabia. Power (that is, oil) does grow out of the barrel of a gun, and indeed, the gendarme of the oil barons continues to hold onto that power with violence, or the threat of it. Nevertheless, domination in capitalist conditions occurs through the mediation of the economy, through the price of oil, for instance, or else through the stark conditions of production in Arabia that enabled petrodollars to be recycled through the U.S. economy, thereby re-creating the United States as the buyer of last resort without too many gunshots. ${ }^{7}$ Such abstract domination confounds the rebels, accustomed as they are to rush the baron's castle or the moneylender's books, to confront a target that is more than the administrator of oppression.

The response to this immanent violence, the CPI suggested, is not necessarily violence itself, for several related reasons. Even by 1924, the level of repressive technology and military might was such that a generally disarmed population could not pursue a frontal attack on the colonial state. Any armed action, therefore, comes in two forms: first, as sporadic violence against individuals who stand in as representatives of abstract domination, but whose own level of culpability is hard to fathom; and second, as guerrilla warfare, attempts to whittle away at state power and, by acts of élan, to appeal to others to join the struggle. Both fail to conduct the three tasks so central to the left movement: to organize people into the struggle, to proclaim one's aims openly, and to overthrow the social relations not just after a coup d'état, but also even as the struggle proceeds. The left today pays little attention to the debates between Lenin and Bernstein (via Kautsky), 8 but it may help us sharpen our sense of what the left movement understands by smash (from Marx, Sprengung, or explosion), as in "to smash the state." Bernstein favored a gradual move to socialism by the reform of the capitalist structure, by the transformation of advanced capitalism into a socialism managed by a state form generally left untouched by the reform process except that it is benevolent rather than malevolent. Better leaders, in other words, can make the state act on behalf of the people. The problem concerns those who are in power and not the configuration of state power that saturates the habits and policies of the state to act at the behest of certain classes. ${ }^{9}$

Lenin, in response, felt that that capitalist state form itself acted to oppress people, and that it was that state form that needed to be shattered or smashed. The distinction is over what to do with the state form, and from that springs the strategic and tactical difference between social democracy and communism. The latter does not ask that the movement kill bureaucrats in a saturnalia of violence. The task of radicalism is to "smash the old bureaucratic machine at once and to begin immediately to construct a new one that will make possible the gradual abolition of all bureaucracy - this is not utopia, this is the experience of the [Paris] Commune, this is the direct and immediate task of the revolutionary proletariat." 10 There is no call 
to indiscriminate violence, but there is a call to radically transform the way in which power operates in society.

While the left is not prone to violence, left organizations and intellectuals do tend to valorize the acts of armed resistance from the working class and peasantry, deeds that come at tremendous cost to those who take to the gun or sword only when imperialist oppression becomes unbearable. We do write paeans to peasant rebellions, but mainly because we want to put on record the enormous courage it took for the masses to break down the walls of agrarian privilege, even as we may in a humanist fashion want to recognize the tenacity of the human spirit lodged in the hearts of the exploited classes. But it is not only the history of the fight that is worthy of respect, for the left does tend to sanction acts of violence against the property of oppression to put on record the frustrations of the people, as well as to inflict pain on property for its violence against everyday people. The wreckage of the storefronts in Seattle mimics the many acts of destruction around the globe by people in those rebellions known as "IMF riots." If liberals want to run away from these acts of violence, the doyens of the right recognize that they are not random, but the necessary response of everyday people to the extension of the global capitalist market. The notorious F. A. Hayek warned that the market approach would produce discontent and lead to "acts of desperation on the part of the needy."11 As Ronald Reagan and Margaret Thatcher looked out at the decade of the 1980s to regulate the world in Hayek's image (without his own foreboding), the Brandt Report on the IMF noted, "The Fund's insistence on drastic measures has tended to impose unnecessary and unacceptable political burdens on the poorest, on occasion leading to 'IMF riots' and even [the] downfall of governments." And the president of the World Bank and former head of the Bank of America Tom Clausen argued, "When people are desperate, you have revolutions. It's in our own evident self-interest to see that they are not forced into that. You must keep the patient alive, because otherwise you can't effect the cure."12 Capitalist globalization (whose current stabilization techniques are encapsulated in IMFundamentalism) produces discontent that, in turn, is the mulch that generates the violence from below. To be indignant about that violence is to forget the social conditions that generate it and the institutionalized powerlessness of the people who turn to such forms of rebellion.

As the left abjured and denounced acts of terror, the representatives of the bourgeoisie tarred it with that liability. For one, there is the tendency to read the exuberant texts (with words like smash and violence) as terrorist documents. To discredit the left, power sought to portray it as a disease whose main vector was random violence. If the left did not act by the playbook of violence, power sent its provocateurs to create havoc in the ranks of the studied opposition. The U.S. left, as many have catalogued, was devastated by this tactic developed to an art in COINTELPRO (Counter-Intelligence Program). Furthermore, power uses the notion of terrorism to 
ferret out all manner of rebels whose opposition inflicts political pain on the regime, just as it calls its own militant partisans freedom fighters. The act of definition to dismiss the work of the opposition is one well cultivated by the U.S. government, creating a vague definition of terrorism (in US Code Title 22, section 265.d, 1983, as "premeditated, politically motivated, violence perpetrated against non-combatant targets by subnational groups or clandestine agents, usually intended to influence an audience") so that it may exculpate its contra allies (secretary of state George Schultz told Congress in 1986 that "once we understand terrorism's goals and methods it is not hard to tell, as we look around the world, who are the terrorists and who the freedom fighters. The Contras in Nicaragua, for example, do not blow up school buses or hold mass execution of civilians").13 In 1918, as one example, Lord Willingdon, the governor of Bombay province, said of Gandhi that he is "Honest, but a Bolshevik and for that reason very dangerous." 14 If power is allowed the latitude to define what is or what is not terrorism, the left has already been put on the road to defeat.

Recently, the U.S. government pronounced the Colombian group Revolutionary Armed Forces of Colombia (Fuerzas Armadas Revolucionarios de Colombia, FARC) a terrorist organization, and there is a sense that Maoist armed rebellion itself constitutes a form of terrorism. To leave the context out of Maoist movements and to occlude the inner-Maoist dialogues about violence serves as a convenient way to dismiss all manner of movements opposing power. Maoism, as a political strategy, is about a people's war, where zones liberated by the partisans of the left fight a conventional war (or guerrilla war) against the military. To call groups as diverse as the Colombian FARC, the Maoists in Nepal and India, and the Peruvian Sendero Luminoso and the Tupac Amaru Revolutionary Movement (MRTA) all terrorists is to miss the ruthless criticism amongst these Maoists of the violence of others. For instance, during the MRTA's capture of the Japanese embassy in Lima, Peru, its leader Nestor Cerpa Cartolini issued a communiqué (no. 3, December 28, 1996) that said, "We don't accept that we continue being compared with Shining Path, an organization that we have repeatedly condemned for the use of irrational violence that affects the people itself," whereas the MRTA operates "within a strict framework of respect for the civil population." 15 Mao, in 1929, strongly disputed "the ideology of roving rebel bands" and its concomitant, "the remnants of putschism."16 Just short of a decade later, Mao explained to his troops that the slogan "Political Power Grows Out of the Barrel of a Gun" did not mean that the gun was the means to power, but that "the Party commands the gun, and the gun must never be allowed to command the Party." 17 Mao, unlike many Maoists today, did not make a fetish of the gun or of the armed struggle. The context of China after the Shanghai massacre of 1928 and into the Yenan years (1937-46) made the gun a necessity, both in the struggle against the armed warlord nationalists and the Japanese imperialists. In 1934 Mao distinguished between terrorism (war against the people) and a "revolutionary war," 
"a war of the masses; it can be waged only by mobilizing the masses and relying on them."18 Even here, even as we may say that violence in all situations is harmful, it cannot be denied that Maoism at its best is far from terrorism and close to the armed struggle for national liberation familiar to any student of the American Revolution.

Only in jail did Bhagat Singh read widely (especially from Marx and Lenin, on the history of the Russian Revolution, and Upton Sinclair, whom he especially loved), reflect in a manner far beyond his youth, and revise many of his theses on political strategy. His letter to his political comrades written on February 2, 1931, comprises a mature analysis of the limitations of the Congress Party and of Gandhi, since both seemed prone to avoid the will of the working class and the peasantry, even as Gandhi fashioned himself the great mobilizer of the peasants. In that letter, Bhagat Singh wrote, "Apparently I have acted like a terrorist. But I am not a terrorist. I am a revolutionary who has got such definite ideas of a lengthy programme as is being discussed here." Again,

Let me announce with all the strength at my command, that I am not a terrorist and I never was, expect perhaps in the beginning of my revolutionary career. And I am convinced that we cannot gain anything through those methods. One can easily judge it from the history of the Hindustan Socialist Republican Association. All our activities were directed towards an aim, i.e., identifying ourselves with the great movement as its military wing. If anybody has misunderstood me, let him amend his ideas. I do not mean that bombs and pistols are useless, rather the contrary. But I mean to say that mere bomb throwing is not only useless but sometimes harmful. The military department of the party should always keep ready all the war-material it can command for any emergency. ${ }^{19}$

Already by October 1930, Bhagat Singh, now only twenty-three years old, had worked out that his earlier phase of "romantic idealism" was politically and morally indefensible. In a fabulous essay entitled "Why I Am an Atheist," Bhagat Singh wrote, "Study was the cry that reverberated in the corridors of my mind. Study to enable yourself to face the arguments advanced by the opposition. Study to arm yourself with arguments in favour of your cult. I began to study. My previous faith and convictions underwent a remarkable modification. The Romance of the violent methods alone which was so prominent amongst our predecessors was replaced by serious ideas. No more mysticism, no more blind faith. Realism became our cult." Then, Bhagat Singh offers his precise formula for political tactics in the modern world: "Use of force justifiable when resorted to as a matter of terrible necessity. Non-violence as policy indispensable for all mass movements." 20

For Bhagat Singh, just as he waited in line to climb the gallows, acts of terror 
against the population were not only morally indefensible, but they were also politically juvenile. Nothing can be gained from acts of ruthless terror. Terrorism is an elitist form of politics because it does not demand contact with the masses and it assumes that the people will rise spontaneously after acts of terror. If freedom fighters or the oppressed take to the gun, it is in times of terrible necessity, only to protect the people from a ruthless state and to overthrow state power, not to use violence to mobilize people. Powerlessness can also grow from the barrel of a gun.

\section{Notes}

Lisa Armstrong, Brinda Karat, Mir Ali Raza, and Usha Zacharias offered robust criticisms of an early draft. Van Gosse must be crazy to have asked me to contribute.

1. I'm stealing the phrase clash of fundamentalisms from the title of Tariq Ali's wonderful account, The Clash of Fundamentalisms: Crusades, Jihad, Modernity (London: Verso, 2002). The phrase McJihad does a lot of analytical work in my account of 9/11: War against the Planet: The Fifth Afghan War, Imperialism, and other Assorted Fundamentalisms (New Delhi: LeftWord, 2002).

2. The important texts by Bhagat Singh and the HRSA are collected in Selected Writings of Shaheed Bhagat Singh, ed. Shiv Varma (Kanpur: Samajwadi Sahitya Sadan, 1996).

3. Quoted in Sumit Sarkar, Modern India, 1885-1947 (New York: St. Martin’s, 1989), 148-49.

4. Shiv Verma, "Introduction," Selected Writings of Bhagat Singh, 39.

5. G. Adhikari, ed., Documents in the History of the Communist Party of India, vol. 2 (New Delhi: People’s Publishing House), 443.

6. Karl Marx, Capital: A Critique of Political Economy, trans. Samuel Moore and Edward Averling (New York: International, 1976), 751.

7. This history is available in Tariq Ali, The Clash of Fundamentalisms and in the third chapter of my War against the Planet, entitled "Tolerance of Arabia."

8. Like others, I thought Kautsky's first name was Renegade for many years!

9. I have collapsed the terms of the debate between Ralph Miliband and Nicos Poulantzas, since I find that they have more in common than their disagreement allowed. Poulantzas's early formulation of the problem of class power is best captured in the phrase "Political power is thus apparently founded on an unstable equilibrium of compromise." Political Power and Social Classes (London: New Left, 1973), 192.

10. V. I. Lenin, The State and Revolution (Peking: Foreign Languages, 1976), 59. Emphasis in original. I recommend for study as well the section entitled "Controversy with the Anarchists," wherein Lenin notes the distinction between the socialists and the anarchists (75).

11. F. A. Hayek, The Constitution of Liberty (London: Routledge, 1960), 285.

12. Willy Brandt, North-South: A Programme for Survival [the Brandt Report] (Cambridge: MIT Press, 1980), 216; and Sunday Times [UK], November 23, 1980.

13. Arnab Goswami, Combating Terrorism: The Legal Challenge (Delhi: Har-Anand, 2002).

14. Sarkar, Modern India, 177.

15. E-mail dispatches from the Burn Archive, University of California-San Diego, 1996.

16. Mao Tse-tung, "On Correcting Mistaken Ideas in the Party," Selected Works, vol. 1 (Peking: Foreign Languages, 1965), 114 .

17. Mao Tse-tung, "Problems of War and Strategy," Selected Works, vol. 2, 225. 
132 Radical History Review

18. Mao Tse-tung, "Be Concerned with the Well-Being of the Masses, Pay Attention to Methods of Work," Selected Works, vol. 1, 147.

19. Bhagat Singh, "Why I am an Atheist," Selected Writings of Bhagat Singh, 123.

20. Che Guevara, decades later, came to the same conclusion: "Terrorism is a measure that is generally ineffective and indiscriminate in its effect, since it often makes victims of innocent people and destroys a large number of lives that would be valuable to the revolution.

Besides it hinders all the more or less legal or semi-clandestine contact with the masses and makes impossible unification for actions that will be necessary at a critical moment." Che Guevara, Guerrilla Warfare, trans. J. P. Morray (New York: Vantage Books, 1961), chap. 1. 